\title{
The cultural significance of the Turkish 9 rhythm: Timing, tradition, and identity
}

\author{
Emir Cenk Aydın ${ }^{1}$
}

\begin{abstract}
Folk music throughout Anatolia and Thrace contains significant information about a performers social experience and background. In Turkey social information is commonly communicated through rhythm. Types of traditional music, particularly types with specific rhythmic structures and patterns, are often indicative of an ethnic or regional Turkish identity, an origin or affiliation. The 9 beat rhythmic structures are very common in the Folk Music of Anatolia. They are seen nearly everywhere in different arrangements and tempo values.

In this article I will discuss the 9 beat time signature and specific $9 / 8$ timed music belonging to and performed by groups that are often considered somewhat marginal in the contemporary Turkish Republic. For example, distinct types of rhythms and music (and corresponding social dances) are performed among defined Turkish identity groups such as Alevi (9/8), Zeybek (9/4 or 9/2), Yörük (9/16), and Rom (9/8). I will pay special attention to nine rhythms and discuss in more detail how each unique rhythmic pattern communicates a great deal of social and regional knowledge in Turkey.
\end{abstract}

Keywords: Turkish 9 Rhythm; Timing; Tradition; Identity; Culture.

\section{Thrace}

The 9/8 rhythm of Thrace is most often heard and seen in the music and dance of people who migrated to Anatolia and Thrace from the Balkans after the Ottoman Empire's collapse. The migrants brought their dances and music to their new places of residence yet did not entirely preserve their musical traditions. The rhythmic repertoire mixed with the local music traditions. Turkish folk dance scholar and Edirne Native Ferruh Ozdincer elaborates on the migrative journey:

The biggest migration from the Balkans to Edirne happened after the Turkish independence war due to the geographical exchange agreements. After the Turkish Republic was founded and during the First World War, migration continued.

The last major link of these migrations happened in 1950-1953. These were mostly families dealing with farming and small scale local trading. After all of the continuous migrations, migrants settled in central villages and indigenous populations moved to establish rural mountain communities. Residents shared and exchanged common cultural traditions and customs, which

\footnotetext{
${ }^{1}$ Dr, Ege University, State Turkish Music Conservatory, Turkish Folk Dances Department, emircenk@gmail.com
} 
caused old traditions to be innovated upon. The outcome is a rich and unique heritage that defines the Edirne City Region (Özdinçer, 2008, s.287).

Immigrants from the Balkans region still inhabit the City of Edirne and its surroundings called "Trakya" (Thrace in Turkish Language). In Turkey, specific music that associates with a Balkan descent are called "Karşlama" and "Hora" and they are very similar in rhythmic patterns. These patterns are in $9 / 8$ time signature. Their order is $2+2+2+3$, and their speed varies from andante to presto. The characteristics of these patterns are the endings in 3 beat part.

Rhythms in Hora and Karşzlama dance and music are usually ordered as below:

Tablo 1: Rhythms in Hora and Karşılama

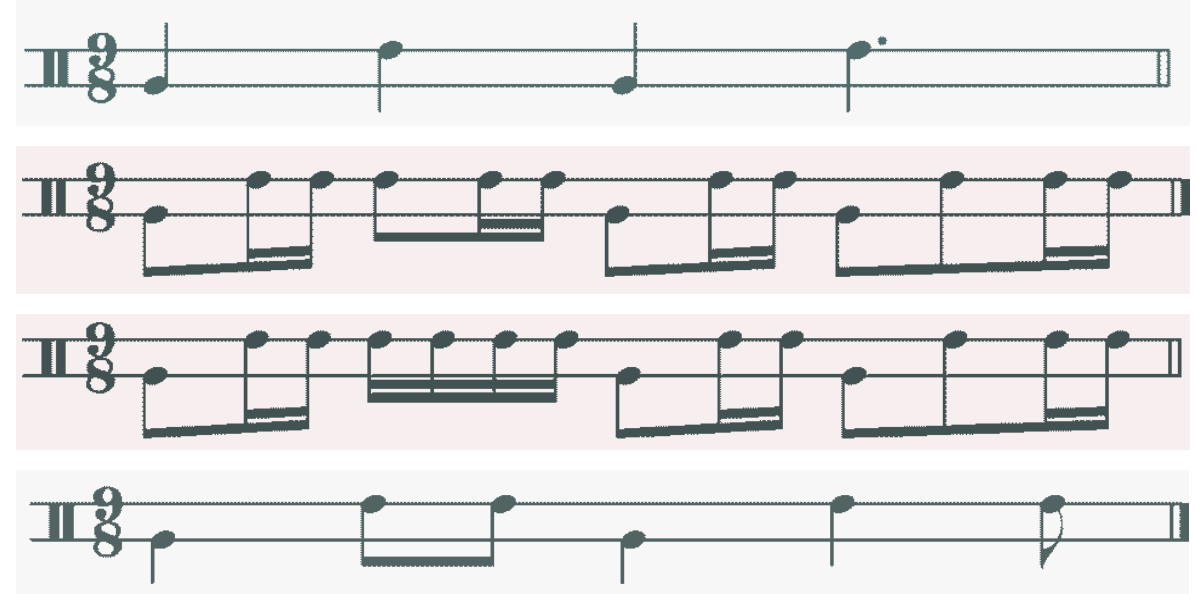

Although the characteristics of the Karşlama rhythmic patterns is the 3 beats in the ending of each bar, the first of these three beats is never an eight note. In addition to Balkan immigrants, Trayke is also a home region to many people of Rom descent. Places like Keşan, Lüleburgaz, and Edirne, for example, have a good portion of Rom population and thus there is the expression of the Turkish "gypsy" 9/8 rhythm that will be discussed in later.

\section{Zeybeks In Aegean Region}

Zeybeks are historically recognized as a group of local authorities that were founded after the Ottoman System collapsed. At this time, the beginning of the $20^{\text {th }}$ century, the social order in Aegea (Western Anatolia) needed to be re-established. Local "Zeybek" heroes (as they were called by the folk that supported them) organized small army-rebel forces on the Aegean mountains and developed a unique cultural and social system for a new Turkish Republic at the local community level. Turkish scholar Ali Haydar Avcı explains:

Thanks to the historical data recordings we have we can asses that the Zeybeks are a subcultural group with a specific set of social structures. Their ways of behavior, traditions, ceremonies, clothing, music, and dances are an expression of their lives and the circumstances that they live in.

Zeybeks have a cultural tradition that enforces social ideals of 'respect to the folk' and 'protect and help the poor and whoever is in need'. This lifestyle has a strong self and societal control mechanism constructed from strong rules. That situation makes the Zeybeks prestigious and respectable in the minds of the Turkish folk (Avc1, 2004, s.22). 
After the foundation of Turkish Republic, one central Anatolian authority was created and the new centralized national authority did not like local forces governing 'their' Aegean mountains anymore. The Zeybeks in the area had two choices. They either cooperated with the new operating national government or were pacified by force. Their former identity as an independent social group disappeared by time as they joined forces with the ruling majority but their dance, music, myths and stories lived on and were passed and preserved from generation to generation. Even if they are not warriors on the mountains anymore, the unique regional Zeybek traditions live in the culture of this specific Anatolian area. Folk dance scholar Ocal Ozbilgin details the origins and origin folk tales of Zeybek culture:

Although many studies were realized about the origin and beginning of Zeybek Mission which we encounter around western Anatolia as a social bandit phenomenon, there is no solid evidence on who 'Zeybek' are and from where their origin is coming. Zeybek mission ended by the time of the foundation of State of Turkish Republic. below:

Claims about the origin of Zeybek mission may be categorized just as under the headings

-Middle East originated Turkmen and Yörük communities

-Aegean Coastal communities, which are originated from Balkans

-Local tribes, which have lived in Anatolia since ancient times

In my opinion, the most reasonable one of the claims about 'where Zeybeks are originated from' is; some Middle Asia originated Turkmen and Yörük communities passing from eastern part of Black Sea towards Thrace stopped and settled in Western Anatolia. After settling along the Aegean shore, these groups in the beginning started to employ themselves as fishermen. They lived in peace until social balance broke down in society of Ottoman Emperor. Naturally they had to replace their social life and security. Some members of this community later started to live a bandit style life, forming small groups and rebelling against the state. According to us, it is not suitable to refer the origin of Zeybeks to ancient civilizations of Anatolia, as some researchers have. But here we need to highlight that high living standards of ancient Anatolian Civilizations which lived especially around the river Büyük Menderes, made great contributions to both social and cultural life of following civilizations (Özbilgin, 2007, s.18-19).

Rhythmically Zeybek dances are the slowest dances in tempo in Anatolia. They are in 9 beat time signatures usually $9 / 4$ or even slower $9 / 2$. As the tradition specifies, the dancer leads the tempo of dancing and music while imitating the movements of an eagle. The dance is often performed drunk in many villages. It is considered a very spiritual movement because the dancers conceptualize and embody the eagle, their totemic notion of common heroic themes like bravery and justice in their performances. In some areas in Aegea, in Aydın City for example, one bar of that $9 / 2$ rhythm would be about 45 seconds; each beat is lengthened and extended by the dancer in an improvisational manner as a fill-in structure. The special arrangement of each beat gives the character of the Zeybek style, which is possible to spot or recognize even if it is only heard from the drums. (In the meaning of only rhythms, without the presence of melody or dance). 
Rhythms in Zeybek dance and music is usually ordered as below:

Tablo 2: Rhythms in Zeybek dance and music
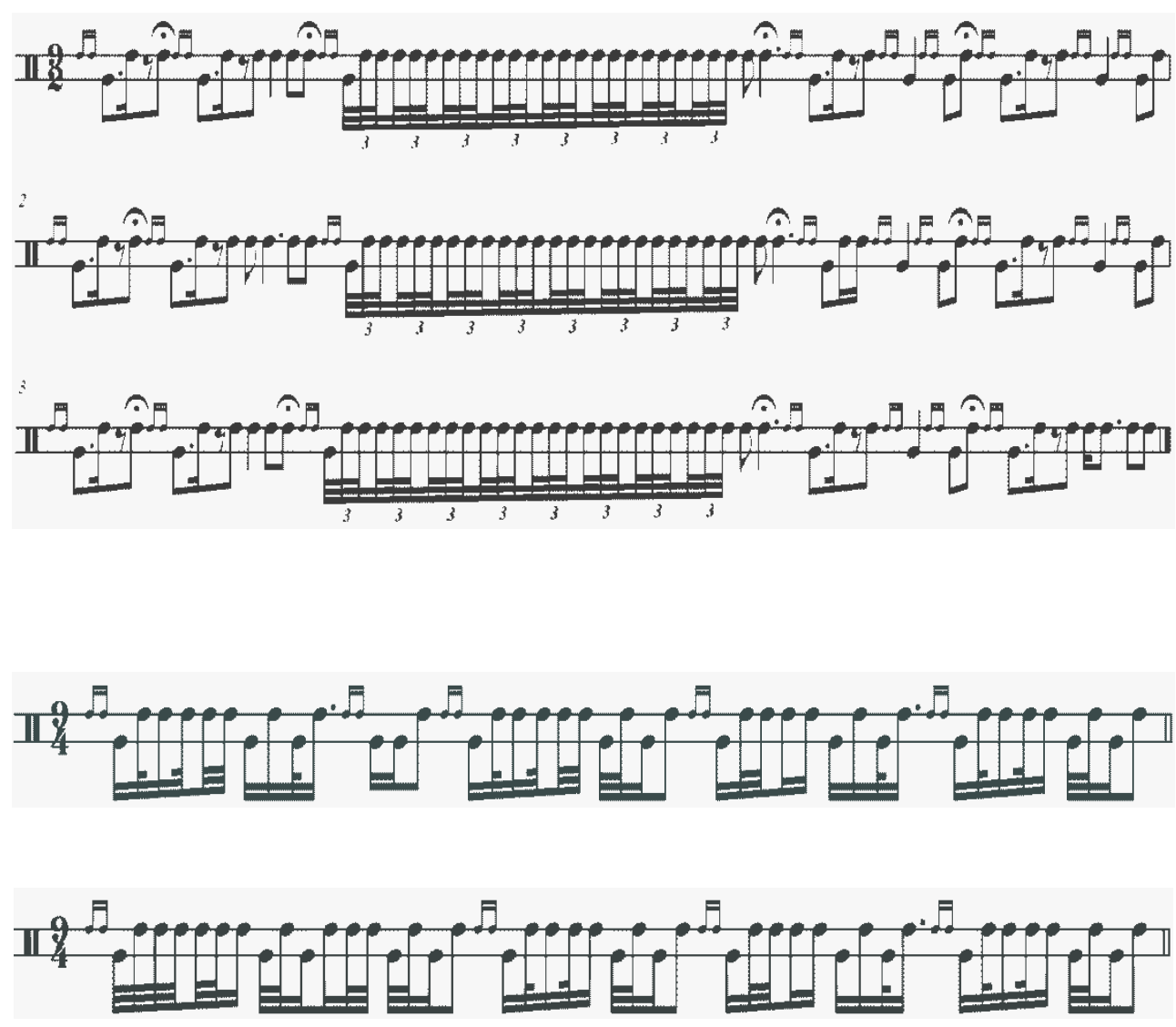

\section{Yörüks}

Yörüles or Türkmens are Ö̆uz Turks who were nomads living on the yayla (high altitude pastures) in the summers when it is hot in lower altitudes and lower plateaus (ova) in the winter up until approximately 80-90 years ago. Yörüks, are historically known as Türkmen (Turcoman), or AlAtrâk, being a branch of the Oguz group of peoples who invaded Asia Minor from the 1020's onwards (İnalc1k, 2014, p.467).

The word 'Yörüke' means Brave, Warrior, Healthy and the word 'Yürük' would usually be used to define groups that are nomads originating from the Ö̌zz Turks of Middle Asia. The migration and settlement of Oghuz groups, who were also known as Turkmens in Anatolia, were closely related with the political and demographic developments in the Great Seljuk Empire (Şahin, 227). The Seljuk/Selcukid central government used to settle them on the East Roman borders-marches. Due to the nature of animal husbandry and seasonal migrations, conflict with the central government, Seljuk or Ottoman, was at times inevitable (İnalc1k, 2014, p.467).

They lived in special tents they make from goat wool and the tents are their homes in every season. Tents are heated with fire inside and they are rainproof, built to withstand the seasonal Anatolian climate.

Türkmen is interpreted to mean "the real Turks," "the Turks of pure blood," or "those Turks who kept their original way of life." (İnalc1k, 2014, p.468). The word Türkmen would apply to people who are from Oğuz Turk descent and are believed to have walked to Anatolia from Middle Asia. By majority, this group later gave up being nomads for permanent settlements. In other 
words, the people who continued on as nomads and lived on the yayla in the winter and on the ova in the summers in order to breed goats and other animals are still referred to in modern day Turkey as Yörüles.

The term "Yürük" derived in Anatolia, used while referring to these nomadic people, was derived from the word "yürü" meaning "walk" using the suffix " $k$ " at the end of the root "yörü" or "yürü". In Ottoman archive documents, the term "Turkmen" is used more while referring to the nomadic people living in central and eastern Anatolia, and the term "yürük" or "yörük" is used when referring to the nomadic people living in the western parts of Anatolia. Yet, it is hard to make a clear distinction between the uses of either terms and the people they refer, because both terms were sometimes used interchangeably within the same context in certain documents while referring to their lifestyle of the same people. Terms including "konar-göçer", "göçer-evli", "göçerler" and "göçebe" were also used while referring to the nomadic people (Şahin, p. 232)

Yörüks started settling in Anatolia about 80-90 years ago, especially in the higher plateaus of Aydın, İzmir, Muğla, Fethiye, Burdur and the Acipayam region, Antalya and cities in west and Southwest Anatolia. Ekişehir, Bilecik, Bursa, Konya are the other major cities in Anatolia that have large Yörük populations. Yörüks are also very high in numbers in the population of Turks living in the Balkans. Many Türkmen and Yörük people went to the Balkans in the Ottoman time, either by their own will or by the population regulation strategies of the Ottoman emperor --the governing people of the new lands in the Balkans were usually selected from Türkmen tribes. Yörüles were often times trusted more than other ethnicities by the Ottoman Emperor because they claimed a pure Turkish lineage coming directly from Middle Asia and were believed to preserve the original Turkish genes which they believe are not mixed with other ethnicities.

In the beginning of the $20^{\text {th }}$ century, Yörïks went through hard times with the collapse of the Ottoman Emperor during the Independence War. Many Yörük folk heroes in Aegea emerged from this war generally referred to under the broader 'Zeybek' category. Yörüles, living on the mountains, rebelled against the authority and attempted to establish their own rules embracing concepts of new societal codes including a new national Turkish identity. Dancing Zeybek is one of the most important components of their renewed folk life. This specific dance is ordered in 9 beats time signatures usually in 9/4 or 9/2 values, much slower in tempo than the dances that Yörüks created who went to the Teke region instead of northwest to Izmir or Aydin Cities.

Yörüles in Teke Region, including the Burdur and Acipayam area have their own stylistic dances and music but as significant as their melodies are, the special 9/16 rhythm is significant to their kind of music. For example, if one hears that special type of 9/16 rhythm, one does not need anything else to recognize the Teke folk region, area, and style. Teke rhythm is perhaps one of the fastest 9 beats rhythms in all Anatolia in tempo. In this music and dance, the dancers imitate the movements of a goat. The word "Teke" means the 'male goat'. This specific Yörïk time signature $9 / 16$, orders $2+2+2+3,2+3+2+2$, speed from allegro to prestissimo. 
Rhythms in Teke dance and music is usually ordered as below:

Tablo 3: Rhythms in Teke dance and music

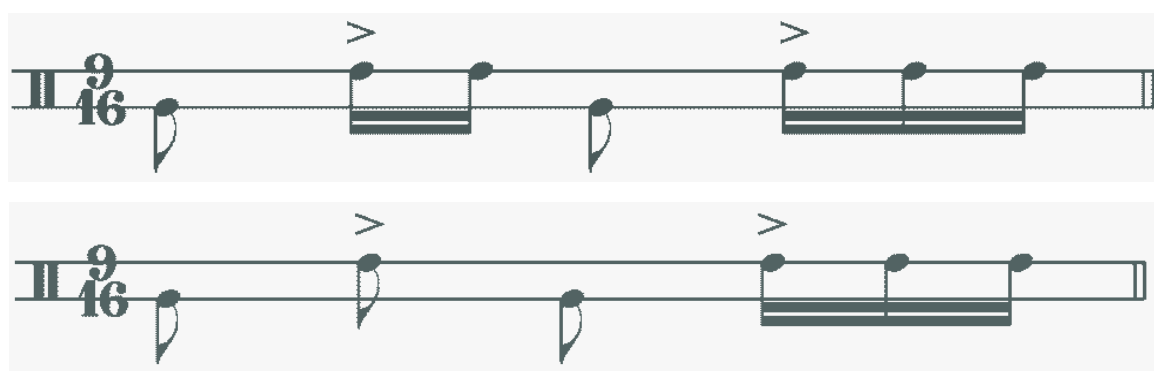

\section{Roman $9 / 8$}

The Turkish rooted Roman Havasi is a dance that generates a great deal of attention from people outside of Rom communities perhaps because it is one that is pelvically virtuous in nature and is usually accompanied by lively dance music. Partially due to video recorded and media broadcast versions of this "belly" dance, a specific movement vocabulary has come to be popularly associated with the Rom ethnic groups regionally situated in Thrace and Anatolia. As a result the Roman Havasi has leant itself to commodification and has frequently become a dance choreographed and performed for a consumer audience.

The Rom people (plural Roma) are members of a minority ethnic group. They recognize a shared heritage originating from the Indian Subcontinent after a westward migration that took place as early as the $11^{\text {th }}$ century About four hundred years elapsed between the Gypsies leaving India and their entrance into Europe. Although there are few references to what might have been Gypsies in Europe before 1400, this was not the norm. The Rom spent many years in Albania, Persia, possibly Arabia and certainly Turkey. While the documentary evidence for this is slim, the linguistic evidence is not (Frazer, 1992, p.38-41).

Roma are spread wide across the globe but high concentrations of such groups remain in Central and Eastern Europe, the area formerly known as the Balkans, and Anatolia. Rom people are also known as Gypsies (Cingene) in the common, daily language of Turks, though now the term is viewed as derogatory among scholars and some members of the Rom community. In contemporary Turkey, the more socially appropriate term for people belonging to Rom social groups is "Roman".

There are more than twenty words, in Turkish, used for Gypsies. Some of them are "Cingene, Kipti, "Posa, "Karac1, "Roman" etc. because of coming from other languages, most of these words can be explained by an etymology of foreign source. (Y1ldı, 2007, p.61-82). But mostly, Gypsies in Turkey are called "Cingene" or "Roman". According to the official figures, the number of the Gypsy population in Turkey is around 500 thousand (according to unofficial figures, it is around 2 million). $95 \%$ of this population is not pursuing a settled life.

The region where Gypsies are densely populated in Turkey is the northwest, which is part of Thracian lands lying within the borders of Turkey (Arayıc1, 2008: 236). Thrace is the name of a region, which is historically very rich, in the Southeastern Europe and involves Southeastern Bulgaria (Northern Thrace), Northeastern Greece (Western Thrace) and Northwestern Turkey (Eastern Thrace). The Gypsies in the Eastern Thrace, which lies within the Turkish border, draw attention with their musical talent like many other communities of Gypsies (Özer, 2013, p.225).

The Rom in Turkey are often associated with some of the lowest socio-economic classes and frequently face discrimination due to ignorant, yet ubiquitous stereotyping by more privileged 
Turkish social classes. Many Rom, if they can find employment, do so as domestic and maintenance workers, street recycling technicians, or metal smiths yet fortunately many take advantage of state sponsored education and are attempting to improve their personal and social conditions. Rom in Turkey are also known (and loved) for their adept ability as musicians, dancers, and entertainers and they are usually hired to play live music at a variety of non-Rom social celebrations including weddings, engagements, and circumcisions as well as public seasonal events.

Although there are many Rom individuals in Turkey who do not perform professionally, music and dance performance at social events is an ordinary element and there is no need to hire professional entertainers for family parties. At their own community celebrations, men and women of all ages are encouraged to get up and express their unique cultural identity to the Roman Havasi music, which always includes the characteristically Turkish aksak (uneven) $9 / 8$ rhythm in the form of 'EVFER'.

Rhythms in Roman dance and music is typically ordered as below:

Tablo 4: Rhythms in Roman dance and music

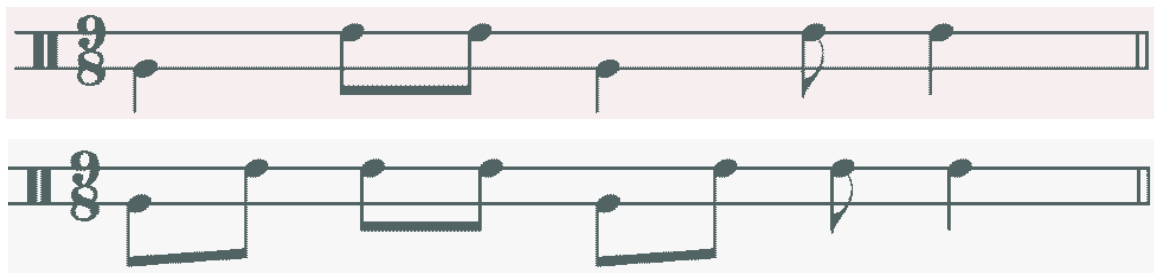

One of the most noticeable characteristics of Roman $9 / 8$ is the last quarter "Tek" note, which is not generally divided in smaller values. The $7^{\text {th }}$ beat of the bar is always an eighth note.

Instruments played for Roman Havasi can vary depending on the geographic location but traditionally a percussive instrument such as davul or doumbek generally has to be present in order to keep the rhythm, as is at least one type of wind instrument such as clarinet, zurna, or saxophone. Other instruments used in a Roman Havası musical piece could be stringed instruments such as kanoun and/or violin. It should be mentioned that live music is not necessary to instigate a performance of the Roman Havasi for the reason that DJs playing recorded music may serve as a substitute for live musicians at contemporary parties and celebrations.

One might characterize the movements that accompany the Roman Havasi music as a type of "Belly Dance" because of the isolated movements of the hips and torso. The movements of the Romans that have been directly observed performed in Izmir at events at a variety of community events are somewhat unique from other "Belly Dances" While other groups around the geographic area including Algeria, Lebanon, and Egypt rapidly gyrate and transversally contort the belly and pelvis in one or more of many ways, the upward thrust of the hips on rhythmic $9 / 8$ time often combined with a delicate back beat flutter of the gluteus and simultaneous bouncing of the belly make Turkish Roman Havasi dancing a distinctive dialect of the overall "Belly Dance" movement system. Additionally Roman Havasi social dancers articulate a wide variety of foot steps that also contribute to the appearance of pelvic partitioning including toe and heal tapping and prances free of head bouncing - all which illustrates the uneven quality of the $9 / 8$ rhythm. 


\section{Tahtaci Alevi People And Semah}

The Alevi are a religious and cultural community with the population nearly 20 million in Turkey. They come from the Bektassi-Sufi lineage within Shi'a Islam, mixing many elements of local Anatolian folk culture. Alevi worship takes place in assembly houses (cemevi). The ceremony (cem) features music and dance (semah) in which both women and men participate. The central Alevi corporate worship service is the cem. The ceremony is symbolic of the prophet Mohammed's ascent into heaven where he gathered with the forty saints who were his followers. According to village myth the semah dance began when Mohammed sat together with his group of forty followers and gave them one grape and from this one grape they all got drunk and began to turn while dancing. Semah is considered as a religious act of worship and is not performed strictly for entertainment of fun. One informant in Akegesme village in the province of Aydın, Turkey explained that semah means to change your direction towards the god and it is something spiritual. The word semah should not be confused with sema, which refers to the dance practice of the followers of Mevlevi who are also known as dervishes.

Tabtac Alevis have different ways than Sunis (majority of Anatolia) for practicing the Islam

Religion. For example Tabtac Alevis who do fast, generally do not observe their major fast for 30 days during the month of Ramazan. The main Tabtac Alevi fast is held during the first 12 days of the Muslim month of Muharrem. Also Tabtac Alevis usually would drink the wine that they make and consider that not conflicting with their religion.

Tabtac Alevi's Semab dance and music is another 9/8 from Anatolia which is specific with its order like below:

tablo 4: Rhythms in Alevi's Semah dance and music

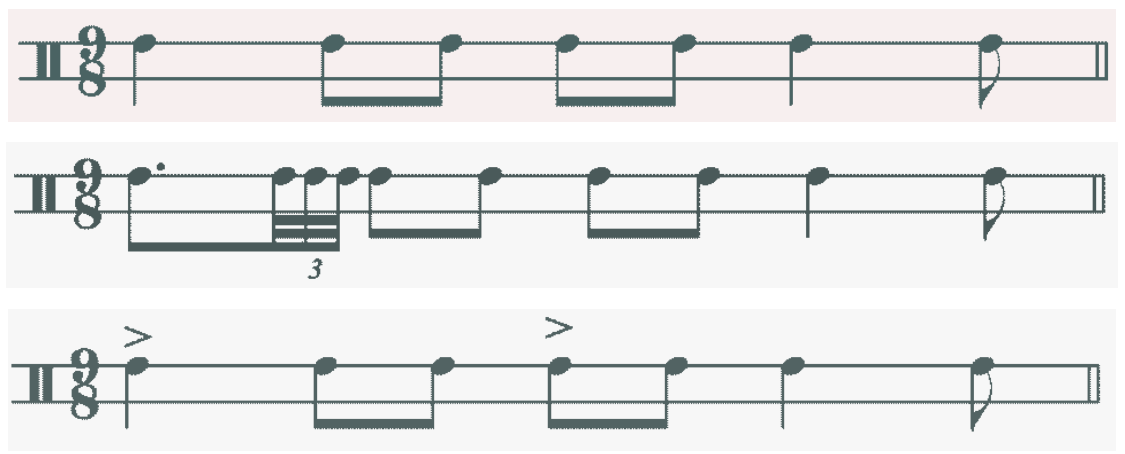

Generally either the dance or the music is in the time signature $9 / 16$, order $2+2+2+3$, $2+3+2+2$, and speed from allegro to prestissimo. The accents are usually on the first and fifth eighth notes. This can be heard from the handclaps of the dancers or the dancers clap their hands on the eighth note that has the accent.

The time signature, the rhythmic pattern and ordering comprise of significant information to determine the type of folk music in the folk music types mentioned above. A rhythmic structural analysis is an excellent way to determine a local and/or regional folk identity. Even if the writer, arranger, or performer is unknown, ethnomusicologists, working with any of the folk music types mentioned above, can assume the origin and affiliation of a song, even if the source is an anonymous one. Rhythmical analysis will help enlighten studies about folk music types and genres in Turkey. 


\section{Bibliography}

1. Arayıc1, A. (2008). Avrupa'nin Vatansı̨lar Çingeneler, İstanbul: Kalkedon yayınları.

2. Avc1, A. H. (2004) Zeybek Concept and History of Zeybeks, Zeybeklik ve Zeybekler Taribi E Yaymlarn Birinci Basım.

3. Duygulu, M. (2006). Türkiye'de Çingene Müriği - Batı Grubu Romanlarnda Müzik Kültürü, İstanbul: Pan Publishing.

4. Fraser, A. (1992). The Gypsies. Oxford: Blackwell Press.

5. Illhan Şahin, The Oghuz Turks of Anatolia, 10/01/2016, http://journals.manas.edu.kg/mitc/oldarchives/2004/29 1007-2465-1-PB.pdf

6. Inalcık, H., (2014) The Yörüks: Their Origins, Expansion And Economic Role Yörükler: CEDRUS The Journal of MCRI

7. Özbilgin, Ö. (2008). Zeybek Dances in the Balkan Peninsula; The Balkan Peninsula as a Musical Crossroad, SOKOM International Conference, Struga, Republic of Macedonia: SOKOM.

8. Özdincer, F. (2008). Hora and Karsilama Dances in Edirne Region First Symposium of ICTM Study Group for Music and Dance in Southeastern Europe. Struga, Republic of Macedonia: ICTM.

9. Yıldız, H. (2007). Türkçede Çingeneler İçin Kullanılan Kelimeler Ve Bunların Etimolojileri, Dil Arastermalar Dergisi,1 (1).

10. Ozer, U., (2013). The Song of the Other/ Public Space as a Learning Environment and Gypsy Musicians in Turkey, Journal for Critical Education Policy Studies (JCEPS), 01/03/2016, http://jceps.com/wp-content/uploads/PDFs/11-4-11.pdf 